\title{
Research on Energy Demand Forecast in Baoding City
}

\author{
Yan-Hui Wang \\ School of Business and Administration, North China Electric Power University, Baoding, Hebei 071000, China \\ Email: wyanhui@126.com
}

\begin{abstract}
With the accelerated pace of integrated development of Beijing, Tianjin and Hebei Province, Baoding is one of the important regions to undertake the transfer of the capital function. It is necessary to forecast the energy demand of Baoding in the next few years. The thesis uses grey relational analysis and analogy method to forecast total power demand. Firstly, the paper calculates the relational degree of Baoding and related cities respectively then chooses some reference cities. The total energy demand is determined by means of weighted average calculation. Finally, according to Baoding Energy Development Planning, coal, oil, natural gas and other energy demand are forecasted.
\end{abstract}

Keywords- integrated development; energy demand; grey relational analysis; forecast

\section{INTRODUCTION}

Currently, the integrated development of Beijing, Tianjin and Hebei Province is increasingly deepened. Beijing has begun to relocate some functions to nearby cities in its neighboring province. Baoding is one of the important regions to undertake the transfer of the capital function. In order to undertake the preparation of the capital function transfer, energy demand will grow substantially. Based on this background, the thesis forecasts the total energy demand in Baoding.

\section{ANALYSIS ON CURRENT SITUATION OF ENERGY CONSUMPTION IN BAODING}

The population and energy consumption data are shown in TABLE I. Baoding has a population of 143.83 million and its total energy consumption of 311.31 tons of standard coal in 2013.

TABLE I. BAODING'S POPULATION AND ENERGY CONSUMPTION IN 2010-2013

\begin{tabular}{lcccc}
\hline \multicolumn{1}{c}{ year } & 2010 & 2011 & 2012 & 2013 \\
\hline $\begin{array}{l}\text { Population } \\
\text { (ten thousand) }\end{array}$ & 131.05 & 142.90 & 142.74 & 143.83 \\
\hline $\begin{array}{l}\text { Total energy consumption } \\
\text { (ten thousand tons of standard coal) }\end{array}$ & 214.33 & 180.27 & 273.70 & 311.31 \\
\hline $\begin{array}{l}\text { Coal consumption } \\
\text { (10000 tons) }\end{array}$ & 174.77 & 165.89 & 241.26 & 268.75 \\
\hline $\begin{array}{l}\text { Oil consumption } \\
\text { (10000 tons) }\end{array}$ & 8.63 & 14.16 & 15.56 & 15.19 \\
\hline $\begin{array}{l}\text { Natural gas consumption } \\
\text { (million cubic meters) }\end{array}$ & 6198.08 & 4116.22 & 7399.82 & 9291.86 \\
\hline $\begin{array}{l}\text { Electricity consumption } \\
\text { (ten thousand kilowatt hours) }\end{array}$ & 483618 & 444888 & 747901 & 830111 \\
\hline $\begin{array}{l}\text { Thermal consumption } \\
\text { (million KJ) }\end{array}$ & 2707575 & 259137 & 2256334 & 1927383 \\
\hline
\end{tabular}

\section{TO SET UP THE FORECAST METHOD}

Based on the integrated development of Beijing, Tianjin and Hebei Province, Baoding city plans urban population to accommodate 5 million people. According to this condition, the thesis adopts analogy method based on Grey Relational Analysis to forecast energy demand.

Firstly, some cities are selected. These cities' urban population of nearly 5 million people, and the industrial structure and the level of per capita consumption are close to the city of Baoding. The relational degree of each city and Baoding is obtained by using the grey relational analysis method. And then choose some as the reference city with more than 0.6 correlation degree. The total energy demand is determined by means of weighted average calculation. Finally, according to Baoding Energy Development Planning, coal, oil, natural gas and other energy demand are forecasted.

\section{A. To Select the Relational Cities}

According to the above conditions, the thesis selects some cities as the relational cities, for example Shijiazhuang, Xi'an and other cities, as shown in TABLE II. 
TABLE II. THE RELATIONAL CITIES

\begin{tabular}{|c|c|c|c|c|c|c|c|}
\hline City & $\begin{array}{l}\text { Urban population } \\
\text { (ten thousand) }\end{array}$ & $\begin{array}{l}\text { Total energy consumption } \\
\text { (ten thousand tons of } \\
\text { standard coal) }\end{array}$ & $\begin{array}{l}\text { Primary } \\
\text { industry } \\
(\%)\end{array}$ & $\begin{array}{c}\text { The } \\
\text { secondary } \\
\text { industry } \\
(\%)\end{array}$ & $\begin{array}{c}\text { The } \\
\text { tertiary } \\
\text { industry } \\
(\%)\end{array}$ & \begin{tabular}{l}
\multicolumn{1}{c}{ Per } \\
capita \\
income \\
(yuan) \\
\end{tabular} & $\begin{array}{l}\text { GDP } \\
\text { (Billion } \\
\text { yuan) }\end{array}$ \\
\hline Shijiazhuang & 534.65 & 5278.70 & $10.10 \%$ & $49.80 \%$ & $40.10 \%$ & 20534 & 4083 \\
\hline Xi'an & 565.16 & 2023.74 & $4.46 \%$ & $42.34 \%$ & $53.19 \%$ & 16365.67 & 2318.14 \\
\hline Chengdu & 595.43 & 3468.38 & $6.90 \%$ & $46.60 \%$ & $46.50 \%$ & 16493 & 3901 \\
\hline Shenyang & 460.49 & 3642.90 & $4.80 \%$ & $50.10 \%$ & $45.10 \%$ & 17013.6 & 3860.48 \\
\hline Harbin & 476.94 & 3775.13 & $13.60 \%$ & $37.60 \%$ & $48.80 \%$ & 14588.6 & 2868.2 \\
\hline
\end{tabular}

\section{B. To Calculate the Relational Degree of Each City}

\section{1) Introduction of Grey Relational Analysis Method}

Grey relational analysis is a kind of multivariate statistical analysis method. Specific steps are as follows.

Firstly, sequences to be analyzed are determined.

Provided that indexes $\mathrm{m}$ composes the index system of customer value evaluation and customers $\mathrm{n}$ are to be appraised, the original index value of every customer constitutes a m-dimension-arrange vector. Then $\mathrm{n}$ vectors constitute a matrix:

$$
\left(X_{1}^{\prime}, X_{2}^{\prime}, \cdots, X_{n}^{\prime}\right)=\left[\begin{array}{cccc}
X_{1}^{\prime}(1) & X_{2}^{\prime}(1) & \cdots & X_{n}^{\prime}(1) \\
X_{1}^{\prime}(2) & X_{2}^{\prime}(2) & \cdots & X_{n}^{\prime}(2) \\
\vdots & \vdots & \vdots & \vdots \\
X_{1}^{\prime}(m) & X_{2}^{\prime}(m) & \cdots & X_{n}^{\prime}(m)
\end{array}\right]
$$

Secondly, dis-dimension is derived:

$$
\left(X_{1}, X_{2}, \cdots, X_{n}\right)=\left[\begin{array}{cccc}
X_{1}(1) & X_{2}(1) & \cdots & X_{n}(1) \\
X_{1}(2) & X_{2}(2) & \cdots & X_{n}(2) \\
\vdots & \vdots & \vdots & \vdots \\
X_{1}(m) & X_{2}(m) & \cdots & X_{n}(m)
\end{array}\right]
$$

Thirdly, consulting sequence is determined.

All maximums of the evaluation indexes chosen from its m-dimension-arrange vector constitute the consulting sequence.

$$
X_{\mathrm{o}}=\left[X_{\mathrm{o}}(1), X_{\mathrm{o}}(2), \cdots, X_{\mathrm{o}}(m)\right]^{T},
$$

Therein: $X_{0}(i)=\max _{1 \leq j \leq n}\left\{X_{j}(i)\right\}, i=1,2, \cdots m$

Fourthly, grey relational coefficient, maximum difference and least difference are determined.

According to formula

$$
\begin{gathered}
\Delta_{0 i}(k)=\left|X_{0}(k)-X_{i}(k)\right|, \\
\text { therein: } i=1,2, \cdots n ; k=1,2, \cdots m
\end{gathered}
$$

Difference matrix is obtained:

$$
\left[\begin{array}{cccc}
X_{01}(1) & X_{02}(1) & \cdots & X_{0 n}(1) \\
X_{01}(2) & X_{02}(2) & \cdots & X_{0 n}(2) \\
\vdots & \vdots & \vdots & \vdots \\
X_{01}(m) & X_{02}(m) & \cdots & X_{0 n}(m)
\end{array}\right]
$$

$$
\begin{gathered}
\Delta(\max )=\max \left\{\Delta_{0 i}(k)\right\}, \Delta(\min )=\min \left\{\Delta_{0 i}(k)\right\} \\
\text { Therein: } i=1,2, \cdots n ; k=1,2, \cdots m
\end{gathered}
$$

Fifthly, relational coefficient is determined.

Relational coefficient is determined according to formula (1).

$$
\xi_{0 i}(k)=\frac{\Delta(\min )+\rho \Delta(\max )}{\Delta_{0 i}(k)+\rho \Delta(\max )}
$$

Therein: $\rho=0.5, i=1,2, \cdots n$.

Then the relational coefficient matrix is obtained as follows:

$$
\left[\begin{array}{cccc}
\xi_{01}(1) & \xi_{02}(1) & \cdots & \xi_{0 n}(1) \\
\xi_{01}(2) & \xi_{02}(2) & \cdots & \xi_{0 n}(2) \\
\vdots & \vdots & \vdots & \vdots \\
\xi_{01}(m) & \xi_{02}(2) & \cdots & \xi_{0 n}(n)
\end{array}\right]
$$

Sixthly, the gray relational degree (GRD), which is determined according to the following formula, is calculated:

$$
\gamma_{0 i}=\sum_{k=1}^{m} \xi_{0 i}(k) \omega_{k}, i=1,2, \cdots, n
$$

Therein: $\omega_{k}$ is confirmed by average value

\section{To Calculate the Relational Degree of Each City}

According to the strategic planning of Baoding industry, the proportion of the three industrial- structure in the future will reach 5\%,55\% and $40 \%$. Taking the three industrial structure as the index, and according to the following formula (1) and formula (2), the relational degree is obtained between Baoding and each city. The calculated result is shown as TABLE III.

$$
\xi_{i}(k)=\frac{\min \min \left|x_{0}(k)-x_{i}(k)\right|+\rho \max \max \left|x_{0}(k)-x_{i}(k)\right|}{\left|x_{0}(k)-x_{i}(k)\right|+\rho \max \max \left|x_{0}(k)-x_{i}(k)\right|}
$$




$$
r_{i}=\frac{1}{n} \sum_{k=1}^{n} \xi_{i}(k) \quad i=1,2, \cdots, n
$$

TABLE III. THE RELATIONAL DEGREE

\begin{tabular}{cccccc}
\hline City & Shijiazhuang & Xi'an & Chengdu & Shenyang & Harbin \\
\hline The degree & 0.756924895 & 0.58888032 & 0.641252 & 0.757835 & 0.449564 \\
\hline
\end{tabular}

D. Baoding Energy Demand Forecast

The thesis chooses the city of degree above 0.6 to be the reference city. The weight is given according to the proportion of the value of the degree. Baoding's per capita energy demand is 7.9794, as shown in TABLE IV.

TABLE IV. TOTAL ENERGY DEMAND IN BAODING

\begin{tabular}{ccccc}
\hline City & Weight & Per capita energy consumption & $\begin{array}{c}\text { Per capita energy demand } \\
\text { in Baoding }\end{array}$ & Total energy demand \\
\hline Shijiazhuang & 0.351076 & 9.8731 & & \\
Chengdu & 0.297425 & 5.8250 & 7.9794 & 3989.7104 \\
Shenyang & 0.351499 & 7.9109 & \\
\hline
\end{tabular}

If the urban population of Baoding reaches 5 million people, then the total energy demand can be 3989.7104 (Ten thousand tons of standard coal).

$$
500 * 7.9794=3989.7104
$$

Considering energy planning of Hebei province and Baoding City, coal, oil, natural gas, new energy and renewable energy sources will account for $76 \%, 13 \%, 7 \%$ and $4 \%$ respectively a few years later in Baoding. When Baoding's population reaches 5 million, coal, oil, natural gas, new energy and renewable energy sources demand will be 3032,519, 297 and 160 (ten thousand tons of standard coal). The data is shown in TABLE V.

\begin{tabular}{|c|c|c|c|c|c|c|c|}
\hline \multirow{2}{*}{$\begin{array}{l}\text { Urban } \\
\text { population } \\
\quad \text { (ten } \\
\text { thousand) }\end{array}$} & \multirow{2}{*}{$\begin{array}{l}\text { Total energy } \\
\text { demand } \\
\text { (ten thousand } \\
\text { tons of standard } \\
\text { coal) }\end{array}$} & \multicolumn{3}{|c|}{$\begin{array}{c}\text { Total energy demand } \\
\text { (ten thousand tons of standard } \\
\text { coal) }\end{array}$} & \multirow[b]{2}{*}{$\begin{array}{l}\text { new energy and } \\
\text { renewable energy } \\
\text { sources }\end{array}$} & \multirow[b]{2}{*}{$\begin{array}{c}\text { Power } \\
\text { (100 million } \\
\text { kilowatt hours) }\end{array}$} & \multirow[b]{2}{*}{$\begin{array}{l}\text { Heat } \\
\text { (million } \\
\mathrm{KJ})\end{array}$} \\
\hline & & Coal & Oil & Natural gas & & & \\
\hline 500 & 3990 & 3032 & 519 & 279 & 160 & 400 & 670 \\
\hline
\end{tabular}

TABLE V. TABLE V BAODING CITY ENERGY DEMAND FORECAST

IV. CONCLUSIONS
After 12th Five-Year, Baoding undertakes industry transfer of Beijing and Tianjin. As a regional central city, 
energy consumption will increase significantly. In order to ensure the healthy development of the city, energy demand in Baoding is predicted.

The forecasting method not only considers the population growth, but also takes into account the future of the industrial structure. The method is reasonable and high reliability.

\section{ACKNOWLEDGEMENT}

The study is subsidized by the Fundamental Research Funds for the Central Universities (North China Electric Power University, No. 2014 MS149).

\section{REFERENCES}

[1] Baoding Municipal Development and Reform Commission. Energy status and energy saving work in Baoding City, 2015

[2] Baoding Municipal Development and Reform Commission. "13th Five-Year" energy development plan of Baoding City, 2015.8

[3] Fei Xiao, McCalley, J.D.Power system risk assessment and control in a multi-objective framework, IEEE Transactions on Power Systems, 24(1):78-85 (2009)

[4] Zuo.YG. and Zheng X.M. An Empirical Study on the Affecting Factors of Tourists' Sense of Security in Tourist Destinations - Case Study of Quanzhou, Fujian Province, Tourism Tribune, vol.27: 49-57 (2012)

[5] National Development and Reform Commission. "12th Five-Year" plan of Renewable energy development, 2012. 